\title{
Host Plants Association with Longhorn Beetles of Food Value: Traditional Knowledge of the Guaraní as Cultural Identity Keepers
}

\author{
Jorge Justino Araujo ${ }^{1,2}$, Héctor Alejandro Keller ${ }^{2,3}$, and Norma Inés Hilgert ${ }^{1,2^{*}}$ \\ ${ }^{1}$ Instituto de Biología Subtropical, IBS-CONICET, Universidad Nacional de Misiones, Puerto Iguazú, Misiones, Argentina. \\ ${ }^{2}$ Facultad de Ciencias Forestales, Universidad Nacional de Misiones, Puerto Iguazú, Misiones, Argentina. ${ }^{3}$ Instituto de \\ Botánica del Nordeste, UNNE-CONICET, Sargento Cabral, Corrientes, Argentina. \\ "normahilgert@yahoo.com.ar
}

\begin{abstract}
The study of plant-insect interactions and how cultural groups perceive and manage them constitutes one of the interests of ethnoentomology. This work describes the association between host plants and longhorn beetles (Order: Coleoptera; Family: Cerambycidae), an important food among the Guaraní peoples of the province of Misiones, Argentina. Different management methods of host tree species are analyzed in order to promote the rearing of larvae for edible use. We also discuss a story about the mythical origin of cerambicids relayed by the Ava Chiripa Guaraní community. We reflect on the importance of the local worldview in the maintenance of ancestral practices, such as the cultural tasks involved in slash-and-burn agriculture and the intimate knowledge of biological relationships between the cerambycids and their woody host plants.
\end{abstract}

Received December 31, 2020

OPENठAACCESS

Accepted June 30, 2021

Published September 14, 2021

DOI 10.14237/ebl.12.1.2021.1743

Keywords Local knowledge, Edible insects, Cerambycidae, Traditional plant management

Copyright @ 2021 by the author(s); licensee Society of Ethnobiology. This is an open-access article distributed under the terms of the Creative Commons Attribution-NonCommercial 4.0 International Public License (https://creativecommons.org/licenses/by-nc/4.0), which permits non-commercial use, distribution, and reproduction in any medium, provided the original author and source are credited.

\section{Introduction}

The study of how people perceive the relationships between humans, plants, and animals is a topic of interest in ethnoecology (Davidson-Hunt 2000), whose focus is to record the ecological knowledge of different human groups (Gerique 2006). Ethnoentomology is the branch of ethnoecology which studies the perception, knowledge, and traditional use of insects by different cultures (Costa Neto 2002; Posey 1987). Ethnoentomology research addresses diverse topics, including research on insects as human food, crop pests, medicines, hallucinogens, ornamentation, management, and their importance to myths and folklore (Posey 1983; Van Itterbeeck and Van Huis 2012). Food use stands out as an important category in traditional and peasant communities (Costa Neto 2004). Around 1,800 edible species are used by more than 3,000 ethnic groups on the planet (Ramos Elorduy 1997), with reports from Asia, Africa, Australia and tropical America (Ramos Elorduy 1997;
Van Itterbeeck and Van Huis 2012). Among the American peoples there is evidence of the consumption of insects up to 9,500 BP (Van Itterbeeck and Van Huis 2012); at present, environmental management techniques have been developed for some host plant species to promote the growth of edible insects (DeFoliart 1995).

The larval rearing of several species of the genus Rhynchophorus (known as palm weevils, order Coleoptera Family: Dryophthoridae), is well known, with tropical palms being the main managed host plants. The consumption of these larvae as a food resource is widely distributed and has frequently been cited (Choo et al. 2009; DeFoliart 1995).

The Cerambycidae family, which encompasses the insects dealt with in this work, is made up of approximately 35,000 species distributed throughout the planet (Monné et al. 2017). They are phytophagous or xylophagous beetles (Kariyanna et al. 2017) commonly known as wood beetles or longhorn 
beetles because of their showy antennae, which are almost always longer than the rest of the body (Martins et al. 2009). In some tree species, adult beetles of this family cut the perimeter of the bark and part of the log from branches forming a ring. This causes the branches to weaken and fall to the ground where female beetles oviposit. Because of this reproductive behavior they are considered a plague in the forestry and fruit-horticultural sectors (Monné et al. 2017). In contrast, when this particular interaction can be promoted, it continues to provide an important food source for some Indigenous Guaraní communities that maintain ancestral practices (DeFoliart 1995).

Little information in ethnoentomological records on longhorn beetles as food can be found in studies carried out among the Guaraní peoples in Argentina. The scarce published scholarship on the subject in local and global literature limits the possibility of an extensive discussion. Indeed, the only antecedents found discuss certain prohibitions or reproductive taboos associated with the use of logs infested by these insects' larvae as firewood. Likewise, certain mythological associations in the Guaraní worldview were recorded for coleopterans from other taxonomic groups, specifically between a bamboo species (Chusquea ramosissima, Poaceae) and beetles of the Dynastidae family (Keller 2003, 2010).

In this study, we analyze the knowledge and practices carried out by Guaraní forest managers from the eastern region of the province of Misiones in relation to the interactions between host plants and longhorn beetles for food use.

\section{Study Site}

The Atlantic Forest of Alto Paraná extends from the western slopes of the Serra do Mar in Brazil to eastern Paraguay and the province of Misiones in Argentina. The forest is $471,204 \mathrm{~km}^{2}$ with only $7 \%$ of its original coverage preserved (Campanello et al. 2019). Archaeological lithic material confirms the Guaraní presence in the Atlantic Forest of Argentina between 900-2000 years B.P. (Noelli 2004). From 1609 to 1767 the study area was part of the Jesuit missions established in the area (Gálvez 1995; Hernández 1913). At present, the Guaraní groups Mbya and Ava Chiripa are settled in the southeastern region of Brazil $(82 \%$ of the total Guaraní population), Paraguay $(15 \%)$ and in the northeast of Argentina in the province of Misiones (3\%) (Jacobsen 2003; Keller 2017; Ladeira and Matta 2004). In the three countries, actions to promote the cultural conservation of the native peoples in this biome began in the late 1980s (Jacobsen 2003).

In Argentina, most of the communities are settled in large extensions of forests with some degree of protection (private or state reserves) (Keller and Prance 2008). The Guaraní in these areas maintain their own political and social structure with a community leader, the cacique, elected in an assembly by the members of each community. As the political chief, he is responsible for the management of resources related to the material environment inside and outside the community and for ensuring harmony and order among the members (Cardozo and Guillen 2012; Gorosito Kramer 2006). Most of the communities maintain a subsistence economy (shifting agriculture, horticulture, and craftwork), supplemented by seasonal work and state assistance (Kujawska et al. 2017; Sánchez and Giraudo 2003). Most settlements have wooden houses and, to a lesser extent, masonry houses, elementary schools, dirt roads, drinking water from the water network or from drilled wells, poor or non-existent electricity service, and partial health care (Cebolla Badie 2013; Crivos et al. 2007).

At present, the Guaraní population in Argentina barely exceeds 6,500 individuals. Approximately 1,000 people belong to the Ava Chiripa ethnic community and the rest to the Mbya community (Azevedo et al. 2009). In the province of Misiones there are around 117 Guaraní settlements, most of which consider themselves part of the Mbya ethnic community within only a few identifying as part of the Ava Chiripa group. Both ethnic communities are affiliated with the Tupi- Guaraní linguistic trunk (Keller 2017). These self-styled village communities retain much of their traditional subsistence practices, such as slash and burn agriculture, gathering, hunting, and fishing (Crivos et al. 2007). Among these peoples, the use, management, and consumption of different resources from Coleoptera, Hymenoptera, and Lepidoptera have been recorded (Araujo et al. 2018).

The promotion of the rearing of larvae of Coleopterans of the Dryophthoridae family (palm weevils) has been reported in several studies (Ambrosetti 1894; Araujo et al. 2018; Cadogan 1992; Cebolla Badie 2009, 2013; Dawson and Gancedo 1977; Martínez Crovetto 1968; Mayntzhusen 2009; Müller 1989). Such practices promote the development of edible larvae of different species of 


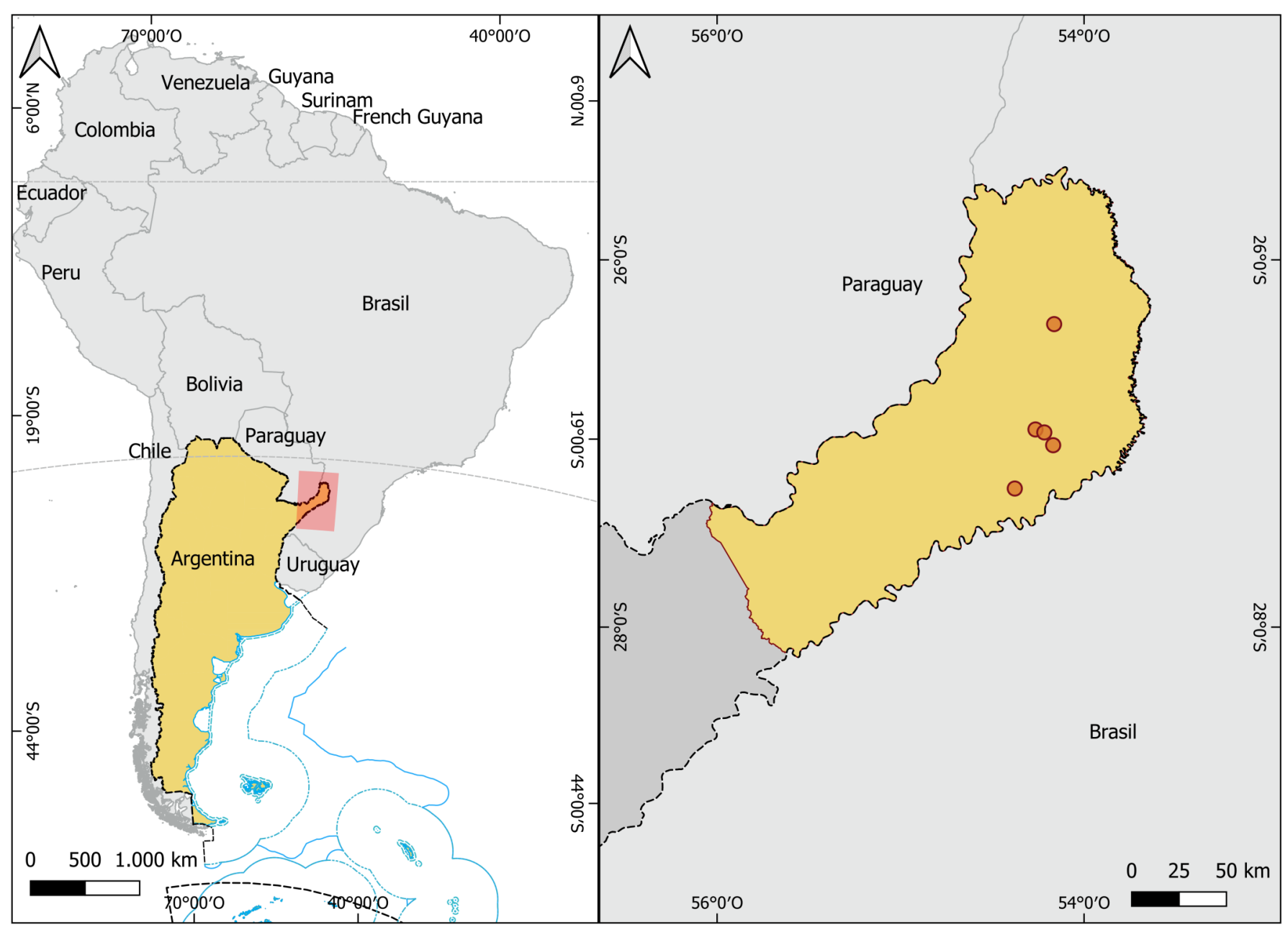

Figure 1 Study area with Guaraní communities visited in orange circles.

curculionids through traditional host plant management techniques.

\section{Methods}

We carried out this research in five villages (Ita Piru with 10 families; Y Akã Porã with 6; Jejy with 70; Chafariz with 25; Teko'a Arandu with 70) of the departments of Guaraní and Eldorado in the province of Misiones, Argentina (Figure 1). This paper reports on data obtained from a total of 20 trips made between 2015 and 2019, involving two to four day stays in each village. Participant observation, ethnobiological walks (guided tours), and semistructured interviews (Albuquerque et al. 2014; Bernard 2000) were carried out to study the management of the production of edible larvae of longhorn beetles. To record management practices related to the production of longhorn beetles of food value, two ethnobiological and observation walks were carried out in Ita Piru and one in each of the remaining villages. The combination of these methodologies allowed us to obtain a detailed account of the set of management techniques, as well as of the different stages the activity comprises, from felling of host trees, monitoring and control of larval development, to collection and consumption. A total of 30 interviews were conducted with individuals of both sexes, male and female family leaders, aged 35 to 80 , estimated to represent $20 \%$ of all families. The interviews were conducted in Spanish and focused on handling techniques, host plant species, time cycles of the activity and productive aspects.

The arboreal host species of edible larvae were identified in the field, and herbarium samples were collected and compared with the material from the CTES herbarium, Instituto de Botánica del Nordeste, Corrientes, Argentina. Once the identification of 
certain species was performed, they were labeled, included in spreadsheets, and their scientific names were updated according to the database of flora names of the Plant List database (http:// www.theplantlist.org/, accessed 08.07.2020). The taxonomic determination of the longhorn beetles was identified from photographs of adult specimens carried out by Dr. Francisco Nascimento of the Museum of Zoology of the University of San Pablo USP, Brazil (family specialist). This study was developed following the guidelines of the code of ethics established by the International Society of Ethnobiology (ISE 2016). For the translation of the expressions in Guaraní, the Cadogan (1992) dictionary was used.

\section{Results}

Host Plants and Management Associated with Cerambycids We registered the cutting of several specific tree species in order to promote the rearing of edible longhorn or wood beetle larvae: yvyra ñechĩ [Balfourodendron riedelianum (Rutaceae)] (Figure 2A); akuchi apia'y [Bastardiopsis densiflora (Malvaceae)]; yvi [Ceiba speciosa (Malvaceae)]; yvyra kachĩ [Lonchocarpus campestris (Fabaceae)]; kurupay [Parapiptadenia rigida (Fabaceae)] and yvyra pyguachu [Phytolacca dioica (Phytolaccaeae)].

In general, adult individuals of longhorn beetles are known to the Guaraní as yvyra ñe kichi a or yvyra jaga'a, meaning "tree cutter" (yvyra refers to the tree or wood, kichi or jaga means to cut, and 'a to fall). Likewise, these insect larvae have a Guaraní zoonym, ycho akambe (ycho-aka-mbe) which translates as "flatheaded larvae" (Figure 2B) referring to the flat shape of their mouthparts in the larval stage.

The Guaraní inhabitants in this study mention that all species of larvae belonging to this group are consumed, with a preference for those that develop large sizes. In this study Orthomegas jaspideus (Figure 2C) and Enoplocereus armillatus (Figure 2D) were identified. While walking through the jungle, they also register trees that have fallen, generally due to winds and storms, and then return to check for developing larvae and collect them in due time.

Two frequent forest management practices are associated with the production of larvae. The first, kokue, occurs in peri-domestic spaces as a secondary result of slashing, the clearing of the forest for agricultural cultivation. The other, in which the cutting of trees is specifically carried out for the
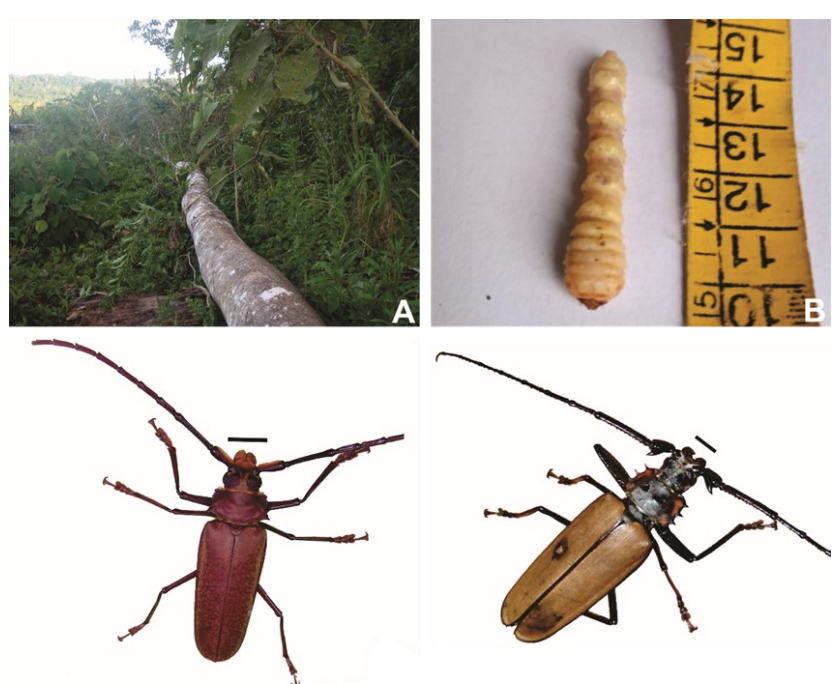

C
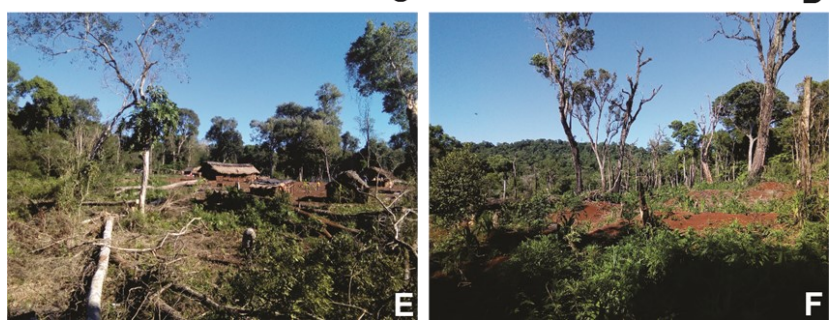

Figure 2 A Tree specimen of yvyra ñechĩ, (Balfourodendron ridelianum) felled for larval production. B ycho akambe edible cerambiciform larva. C Orthomegas jaspideus (scale-1 cm). D Male adult insect Enoplocereus armillatus (scale-1 cm). E Preparation of the land for agriculture. $\mathbf{F}$ Growing area.

production of larvae, is developed outside the peridomestic environment and requires the location and prior selection of the individuals to be felled. Special days are dedicated to felling the trees, as well as for monitoring and collecting larvae.

In the first type of management, the kokue, is located in spaces near the households -oga- (Figure 2E). The Guaraní observe the presence of takuapi cane [Merostachys claussenii (Poaceae)] to define the site of a new cultivation area, as they consider the species a good indicator of the quality of soils for this purpose. To perform the kokue, the Guaraní fell trees and subsequently dry and burn them. Once the burning has been carried out, the area is cleared and the soil is left free from obstacles for sowing (Figure $2 \mathrm{~F})$. When there is abundant bamboo, the burning is fast and superficial which promotes, according to some Ava Chiripa interlocutors, a greater degree of larval infestation in the remaining trunks. 
In the second type of management, to produce food larvae within the forest, trees are cut down and left where they fell. If the logs are very long, curved or inclined, they are sectioned so that they rest completely on the ground. To increase the production of larvae, it is recommended to cut the trees during new moon (Guaraní: jachy ray), since according to the Guaraní, the insect activity increases in this lunar phase. The promotion of larvae rearing takes place during spring and summer. This productive time is called karu porã (good nutrition) given the abundance of resources. After a certain time, all the felled trees are visited and the degree of larval infestation is evaluated observing the amount of sawdust along the trunk surface (Figure 3A and Figure 3B). White or reddish sawdust indicates the beginning of the infestation, while black (due to the degree of sawdust decomposition through time) indicates that larvae are in an advanced stage of development.

Some host species require differential management to promote larval development, as is the case for Ceiba speciosa (A. St.-Hil.). Once the specimen is cut down, it is covered with leaves and dry reeds of Merostachys claussenii (Munro) and a fire is lit so that a superficial and rapid burning occurs.

Another difference indicated by the Guaraní communities in association with the host species refers to the place on the stalk in which larvae develop (that is, the plant structure). In most of the managed species, larvae develop inside the wood or secondary xylem. However, in the Balfourodendron ridelianum it occurs mainly in the inner bark or secondary phloem (Figure 3C).

Larvae rearing takes between five and six months from felling to harvest. They are collected when close to the pupal stage (Guaraní: ycho aguyje). The testimonies collected, and the practices observed, highlight the local knowledge of Guarani of the biological cycle of these insects, particularly the scarce monitoring they perform on felled trees and the temporal precision with which they decide to harvest.

To collect the larvae (Figure 3D), alternate longitudinal and oblique cuts of the stalk are made so that portions can be lifted and detached without damaging the larvae produced. The harvested larvae (Figure 3E) are transferred to households for their preparation in containers usually improvised with part of the host tree bark. In the domestic environment, the larvae are roasted on a spit, traversed by a rod or a toothpick that allows them to be held over the heat of the flame (Figure 3F). This traditional food has a religious connotation that knowledge holder Marciana Franco of Teko'a Arandu explained in the following way in a 2017 interview: "Ycho akambe ñanderu oejava'ekue oreve, iporã (our father has left the flatheaded larvae for us, it's a very good thing). This consumption contributes to the transmission of knowledge associated with the worldview and the reinforcement of self-identity. The cutting of trees to promote the production of edible larvae does not always render the initial expected result; either due to adverse environmental conditions (e.g., temperature, abundant rainfall, and excess humidity), or because wild predators access the resource before its "promoters". These predators include the coati [Guaraní: chi'y (Nasua nasua)], armadillo [Guaraní: tatuái (Dasypus novemcinctus)], and several species of woodpeckers Guaraní: [pekêu rata (Dryocopus lineatus, D. galeatus, and Campephilus robustus)].

\section{Myth of the Origin of Wood Beetles}

In general terms, the Guaraní call mythical stories mboryau, which refers to stories in which events that occurred in remote times are narrated. Below, we transcribe a myth relayed by knowledge holder Verã Tataendy of Ita Piru in 2016 that deals with the importance of longhorn beetles yyyra ñe kichi' $a$ in the narratives of the Guaraní Ava Chiripa:

"Che amombe'uta py pe yyyra ñe kichi'a yma upéicha a'ete ñande Mbya jaiko árami oikó rakae, ojapokue, aupéi oity yvyra, omopoti ñoty avati, upéicha gueri oñoty. Upéicha varirete koata koanga peve péicha chapy 'ante ovaêramo ára pyau ja'erami a'e jepi oikó aguerami yma oikóaguerami teopy oikó aramingua yvyra oity jepikóvy, ja 'endu ko ka'aguyre yvyra rakã o' a ja endu a'e.

Aramingua rupity araminguare a'e jepi oity yyyra oikóvy ava, upéicha árami javemapy ñande kuery ja kopi, ña mopotĩ, ña ñoty anguã, a'e upéicha reñoty rupi. A rire tiko péicha ñande kuery a'ete jaiko, yyyra ne kiti'a ja a'e árami ata koangapeve a'e ombaapo oikóaguerami, ni nda echarái jepi vave ára a'erami a' ekuery yyyra oity koapy ".

Which translates as:

In remote times the ancestral tree feller (longhorn beetle) lived in the way we, Guaraní people, live today. He cultivated, cut down trees, weed and sowed corn, in this way he worked the land. So, at present, when spring arrives, the tree-felling beetle lives in 
the same way as the original tree-felling beetle lived, with the same customs he lives today, and continues to fell trees. When we hear the branches of the trees fall in the jungle, we hear him working.

Currently the tree-felling beetle cuts the trees to live, in this way we have learned to weed, clean to cultivate, and sow, we have learned that this is how we should cultivate. Today, we, Guaraní people, live in the same way as the tree- felling beetle, they continue to work and do not forget the ancestral tree feller, the one who fell trees.

\section{Discussion}

In this work, we analyze Indigenous knowledge related to the biological interactions between host trees and longhorn beetles of mythical relevance and food importance. The Guaraní identify the insect herbivory of the wood beetles and promote this process for the development of larvae production through forestry management techniques. The articulation with data from the Indigenous cosmology, especially with the origin myth of the long-horned beetle, is perceived as related to agricultural practices. The way these insects manage sites to lay their eggs, by cutting branches, reflects the ancestral identity of the Guaraní people as slash and burn farmers, since the felling of trees is the first step on these agricultural practices. In this way, the myth explains that to the sound of large branches falling from attacked trees is considered an indicator of the beginning of a new cycle of agricultural activity, and as such, the propitious time for rearing larvae.

In the local cosmology, the promotion of larval rearing and agriculture are in close interaction, including a set of tasks such as felling trees, weeding, soil treatment, planting, and subsequent harvesting of crops. Reinforcing this idea, the month of August, which corresponds to the cultivation season is called tajy poty, the flowering period of Handroanthus heptaphylus (Mart. ex DC., Bignoniaceae) (Müller 1989), and is recognized as the appropriate month to start the rearing of coleopteran larvae (Cadogan 1992).

One of the management practices carried out by the Guaraní to produce edible larvae is that observed in the superficial burning of Ceiba speciosa. According to the literature, light combustion could increase the release of volatile substances from inside the stems that function as attractants for adult insects for oviposition (Allison et al. 2004; Hanks and Millar 2016). It has also been found that host plants emit fragrance after being cut and adult insects identify them as appropriate for oviposition (Bruce 2015; Hanks and Millar 2016). This insect-plant interaction is a common co-evolutionary process over time (Calatayud et al. 2018).

In the production of food from these wood beetles, we have not observed the practice of making wedge-shaped incisions at constant distances on the tree logs to promote the development of larvae as is the case for weevils of the Dryophthoridae family, (Araujo et al. 2018). Unlike the latter, adult longhorn beetles lay their eggs directly on the bark of fallen trees. Given this behavior, the Guaraní state that these insects have "hard teeth" taí atave, in reference to their ability to make galleries inside the stems and feed on very hard wood, making it unnecessary to open notches in the trunks to enable oviposition.

Reinforcing the traditional management practices carried out on the host plants, in the narrative of the myth it is reflected that in ancient times the original longhorn beetle, yyyra ñe kichi'a ypy, had a certain human nature and that it has recently become a "tree felling" longhorn beetle. In this regard, it is recurrent that in the mythological conceptions of the world in Amerindian cultures there are no differences or dichotomies between human beings, and certain species of plants and animals which vary according to the ethnic group (Keller 2017). Although not explicitly mentioned in the present registry, Guaraní myths about the origin of plants and animals suggest that insects may come from a human being transformed through metempsychosis, reincarnation into other living organism after death, as a result of having transgressed certain sociocultural norms (Cadogan 1959; Cebolla Badie 2013; Keller 2017). Myths generally correspond to different forms of conception of the world, on the basis of which religious representations can be developed (Mayntzhusen 2009).

\section{Conclusion}

The practices carried out by the Guaraní to promote the production of different edible larvae of longhorn beetles reflect a comprehensive and detailed knowledge of the interactions between plants and insects. They also denote precise knowledge of these insects' ecology (especially their biological cycle) and of uncontrollable factors intervening in the success of 
the production (like the predators' consumption of the larvae).

In this study we observed that in Guaraní conception, larval rearing and agriculture, including a set of tasks such as felling trees, weeding, soil treatment, planting and subsequent harvesting, are in close interaction. Further, in Guaraní mythology, the associations between plants, longhorn "tree-felling" beetles and traditional agriculture show that these insects are linked in Guaraní cosmology. Retelling stories which refer to these complex relationships is also an important means of transmitting knowledge. In fact, through them, elders pass on a pragmatic set of traditional management practices to the young that reinforce patterns of behavior oriented to preserve their ancestral cultural identity.

\section{Acknowledgments}

To the members of the Guaraní communities visited for the information provided in this work. To Dr. Francisco Nascimento from the Museum of Zoology of the University of San Pablo USP, Brazil for identifying the species of the longhorn beetles. To Juan Ariel Insaurralde for the design the Figure 1. To Haydée González for the English revision. To CONICET for financing this study.

\section{Declarations}

Permissions: None declared.

Sources of funding: None declared.

Conflicts of Interest: None declared.

\section{References Cited}

Albuquerque, U. P, L. V. F. C. Cunha, R. F. P. Lucena, and R. R. N. Alves. 2014. Methods and Techniques in Ethnobiology and Ethnoecology. Springer New York, New York, USA. DOI:10.1007/978-14614-8636-7.

Allison, J. D., J. H. Borden, and S. J. Seybold. 2004. A Review of the Chemical Ecology of the Cerambycidae (Coleoptera). Chemoecology 14:123150. DOI:10.1007/s00049-004-0277-1.

Ambrosetti, J. B. 1894. Los Indios Cainguá del Alto Paraná. Boletín del Instituto Geográfico Argentino 15:661 -744 .

Araujo, J. J., H. A. Keller, and N. I. Hilgert. 2018. Management of Pindo Palm (Syagrus romanzoffiana Arecaceae) in Rearing of Coleoptera Edible Larvae by the Guaraní of Northeastern Argentina.
Ethnobiology and Conservation 7:01. DOI: 10.15451/ ec2018-01-7.01-1-18.

Azevedo, M., A. Brand, A. M. Gorosito, E. Heck, B. Meliá, and J. Servín. 2009. Guarani Retã 2008, los pueblos Guaranies en las Fronteras, Argentina, Brasil y Paraguay. AGR. Servicios gráficos, Asunción.

Bernard, H. R. 2000. Social Research Methods Qualitative and Quantitative Approaches. Sage Publications, University of Florida, Gainesville, FL.

Bruce, T. J. I. 2015. Interplay between Insects and Plants: Dynamic and Complex Interactions that have Coevolved over Millions of Years but Act in Milliseconds. Journal of Experimental Botany 66:455465. DOI:10.1093/jxb/eru391.

Cadogan, L. 1959. Ayvu Rapyta. Textos Miticos de los Mbyá-Guarani del Guairá. Biblioteca Paraguaya de Antropología. Fundación "Leon Cadogan". CEADUC-CEPAG.

Cadogan, L. 1992. Diccionario Mbya-Guarani-Castellano. Biblioteca Paraguaya de Antropología, Asunción 17:1-211.

Calatayud, P. A., N. Sauvion, and D. Thiéry. 2018. Plant-Insect Interactions. Ecology- Oxford Bibliographies.

Campanello, P. I., J. Von Below, N. I. Hilgert, C. L. Cockle, M. Villagra, D. D. Francescantonio, D. S. Garcia, M. Jaramillo, O. A. Gauto, and G. Goldstein. 2019. ¿Es Posible el uso Sostenible del Bosque en Misiones? Necesidades de Manejo a Diferentes Escalas, Investigación, Intervenciones de alto Impacto y Más Recursos Económicos. Ecología Austral 29:122-137.

Cardozo, T., and F. M. Guillen. 2012. TAPE APOPromovido, Visibilizado y Preservado el Patrimonio Cultural Tangible e Intangible de las Comunidades Mbyá Guaraní del Bosque Atlántico del Alto Paraná. Proyecto 09-CAP2-1437ONGD Cives Mondi.

Cebolla Badie, M. V. 2009. El Conocimiento y Consumo de Himenópteros, Coleópteros y Lepidópteros en la Cultura Mbya-Guaraní, Misiones, Argentina. In Manual de Etnozoología, edited by E. M. Costa Neto, D. Santos Fita, and M. Vargas Clavijo, pp. 215-223. Tundra ediciones, Valencia.

Cebolla Badie, M. V. 2013. Cosmología y Naturaleza Mbya-Guaraní. Tesis de doctorado, Programa de 
Doctorado en Antropología Social y Cultural, Departamento de Antropología Cultural e Historia de América y África. Facultad de Geografía e Historia, Universidad de Barcelona. Barcelona, España.

Choo, J., E. L. Zent, and B. B. Simpson. 2009. The Importance of Traditional Ecological Knowledge for Palm-Weevil Cultivation in the Venezuelan Amazon. Journal of Ethnobiology 29:113-128. DOI:10.2993/0278-0771-29.1.113.

Costa Neto, E. M. 2002. Manual de Etnoentomología. Manuales \& Tesis SEA, 4. Sociedad Entomológica Aragonesa. Zaragoza.

Costa Neto, E. M. 2004. Implications and Applications of Folk Zootherapy in the State of Bahia, Northeastern Brazil. Sustainable Development 12:161-174. DOI:10.1002/sd.234.

Crivos, M., M. R. Martínez, M. L. Pochettino, C. Remorini, A. Sy, and L. Teves. 2007. Pathways as" Signatures in Landscape": Towards an Ethnography of Mobility Among the Mbya-Guaraní (Northeastern Argentina). Journal of Ethnobiology and Ethnomedicine 3:2. DOI:10.1186/1746-4269-3-2.

Davidson-Hunt, I. 2000. Ecological Ethnobotany: Stumbling Toward New Practices and Paradigms. In: MASA Journal, Spring 2000, Volume 16:1-13

Dawson, G., and O. Gancedo. 1977. La Palma Pindó (Syagrus romanzoffianum) y Su Importancia entre los Indios Guayaquí. Obra Cent. Mus. La Plata 2:339353.

DeFoliart, G. R. 1995. Edible Insects as Minilivestock. Biodiversity and Conservation 4:306-321. DOI:10.1007/BF00055976.

Gálvez, L. 1995. Guaranies y Jesuitas. De la Tierra sin Mal al Paraíso. Buenos Aires: Ed. Sudamericana.

Gerique, A. 2006. An Introduction to Ethnoecology and Ethnobotany. Theory and Methods - Integrative Assessment and Planning Methods for Sustainable Agroforestry in Humid and Semiarid Regions Advanced Scientific Training. Loja, Ecuador.

Gorosito Kramer, A. M. 2006. Liderazgos guaraníes. Breve Revisión Histórica y Nuevas Notas Sobre la Cuestión. Avá 9:11-27.

Hanks, L. M., and J. G. Millar. 2016. Sex and Aggregation-Sex Pheromones of Cerambycid
Beetles: Basic Science and Practical Applications. Journal of Chemical Ecology 42:631-654. DOI:10.1007/ s10886-016-0733-8.

Hernández, P. 1913. Organización Social de las Doctrinas Guaranies de la Compañia de Jesús. Gustavo Gili, Barcelona.

ISE. 2016. International Society of Ethnobiology. Código de ética. Código de ética de la Sociedad Internacional de Etnobiología.

Jacobsen, T. R. 2003. Endangered Forest, Vanishing Peoples: Biocultural Diversity and Indigenous Knowledge. In Atlantic forest of South America. Biodiversity Status, Threats, and Outlook, edited by L. G. Galindo and I. Gusmao do Camara. Island Press, Washington D. C.

Kariyanna, B., M. Mohan, and R. Gupta. 2017. Biology, Ecology and Significance of Longhorn Beetles (Coleoptera: Cerambycidae). Journal of Entomology and Zoology Studies 5:1207-1212.

Keller, H. A. 2003. Mythical Origin of Chusquea ramosissima (Poaceae), the Ancient Knife of the Guaranis. Economic Botany 57:461-471.

Keller, H. A. 2010. Plantas Relacionadas con Tabúes del Ciclo Reproductivo de los Guaraníes de Misiones, Argentina. Boletin de la Sociedad Argentina de Botánica 45:201-208.

Keller, H. A. 2017. La Fotosintesis de la Cultura: Estudios Etnobiológicos en Comunidades Guaranies de Misiones, Argentina. Centro de Estudios Antropológicos de la Universidad Católica de Asunción, Paraguay.

Keller, H. A., and G. T. Prance. 2008. Plants Associated with Fish by the Guaraníes of Misiones Argentina. Ethnobotany 20:1-8.

Kujawska, M., N. I Hilgert., H. A. Keller and G. Gil. 2017. Medicinal Plant Diversity and Inter-Cultural Interactions between Indigenous Guaraní, Criollos and Polish Migrants in the Subtropics of Argentina. PLoS ONE 12:e0169373. DOI:10.1371/ journal.pone.0169373.

Ladeira, M. I., and P. Matta. 2004. Terras Guaraní no Litoral: As Matas que Foram Reveladas Aos Nossos Antigos Avós $=$ Ka'aguy Oreramói Kuéry Ojou Rive Vaekue' ỹ. Centro de Trabalho Indigenista.

Martínez Crovetto, R. N. 1968. La Alimentación Entre los Indios Guaraníes de Misiones. 
Etnobiológica 4:1-24.

Martins, U. R., M. H. M. Galileo, and F. L. Oliveira. 2009. Cerambycidae (Coleoptera) do Estado do Maranhão, Brasil. Papéis Avulsos de Zoologia 49:229_ 247. DOI:10.1590/S0031-10492009003800001.

Mayntzhusen, F. 2009. Los Aché Guayakí. Ed. Junta de Estudios Históricos de Misiones. Misiones, Argentina.

Monné, M. L., M. A. Monné, J. P. Botero, V. S. Machado, A. Carelli, M. Cupello, and R. Souza. 2017. Espécies de Cerambycidae, Disteniidae e Vesperidae (Insecta, Coleoptera) Registradas no Estado do Mato Grosso do Sul, Brasil. Iheringia, Série Zoologia 107. DOI:10.1590/16784766e2017119.

Müller, F. 1989. Etnografía de los Guarani del Alto Paraná. Societatis Verbi Divini, Argentina.

Noelli, F. S. 2004. La Distribución Geográfica de las Evidencias Arqueológicas Guaraní. Revista de Indias 64:17-34.

Posey, D. A. 1983. Ethnomethodology as an Emic Guide to Cultural Systems: the Case of the Insects and the Kayapó Indians of Amazonia. Revista
Brasileira de Zoologia 1:135-144. DOI:10.1590/S0101 -81751982000300001.

Posey, D. A. 1987. Temas e Inquirições em Etnoentomologia: Algumas Sugestões Quanto à Geração de Hipóteses. Boletim Museu Paraense Emilio Göeldi, ser. Antropologia 3:99-134.

Ramos Elorduy, J. 1997. Insects: A Sustainable Source of Food? Ecology of Food and Nutrition 36:247-276. DOI:10.1080/03670244.1997.9991519.

Sánchez, A., and A. R. Giraudo. 2003. The Loss of Mbyá Wisdom: Disappearance of a Legagy of Sustainable Management. In Atlantic forest of South America. Biodiversity Status, Threats, and Outlook, edited by L. G. Galindo and I. Gusmao do Camara. Island Press.

Van Itterbeeck, J., and A. Van Huis. 2012. Environmental Manipulation for Edible Insect Procurement: a Historical Perspective. Journal of Ethnobiology and Ethnomedicine 8:3. DOI:10.1186/1746-4269-8-3. 